\title{
Pengaruh Imbuhan Tepung Daun Kelor (Moringa oleifera Lam.) pada Pakan terhadap Bobot Beberapa Organ Dalam dan Lemak Abdominal Itik Pengging (Anas platyrhyncos)
}

\section{Effect of Moringa oleifera Lam. Leaves Meal as Feed Additive on the Weight of Several Internal Organs and Abdominal Fat of Pengging Duck (Anas platyrhyncos)}

\author{
Dara Puspita Jati Windoro, Kasiyati*, Muhammad Anwar Djaelani, Sunarno \\ Program Studi Biologi Fakultas Sains dan Matematika Universitas Diponegoro \\ *Email: atie_bd@yahoo.co.id
}

Diterima 27 Juni 2019 / Disetujui 23 April 2020

\begin{abstract}
ABSTRAK
Daun kelor (Moringa oleifera Lam.) mengandung antioksidan, vitamin C, vitamin A, kalsium, protein, dan berbagai macam asam amino. Semua kandungan nutrien tersebut berperan penting dalam menunjang produktivitas itik pengging, baik daging maupun organ dalam. Penelitian ini bertujuan untuk menganalisis pengaruh imbuhan tepung daun kelor pada pakan terhadap bobot organ dalam dan lemak abdominal itik pengging. Penelitian menggunakan Rancangan Acak Lengkap (RAL) yang terdiri atas 5 perlakuan dengan 3 kali ulangan, yaitu kelompok kontrol dan perlakuan pakan basal yang diberi suplemen tepung daun kelor 2,5; 5; 7,5 dan 10\%. Pemberian pakan dan minum dilakukan secara ad libitum. Data dianalisis dengan pola distribusi normal dan homogenitas data, kemudian untuk mengetahui perbedaan antarkelompok, data dianalisis dengan ANOVA-satu arah. Hasil penelitian menunjukkan bahwa imbuhan suplemen tepung daun kelor pada pakan itik pengging tidak berpengaruh signifikan $(\mathrm{P}>0,05)$ terhadap bobot jantung, limpa, lambung, dan lemak abdominal itik pengging. Kesimpulan dari penelitin ini adalah imbuhan tepung daun kelor pada pakan tidak meningkatkan bobot jantung, limpa, dan lambung, serta tidak menurunkan lemak abdominal itik pengging.
\end{abstract}

Kata kunci: daun kelor, jantung, limpa, lambung, lemak abdominal, itik pengging.

\begin{abstract}
Moringa leaves (Moringa oleifera Lam.) contain antioxidants, vitamin C, vitamin A, calcium, protein, and various kind of amino acids. All these nutrient have an important role in supporting the productivity of Pengging ducks, both meat and internal organs. The aimed of this study analyze the effect of moringa leaves meal as feed additive on the weight of internal organs and abdominal fat of Pengging ducks. This research used a Completely Randomized Design (CRD) consisting of 5 treatments with 3 repetitions, i.e. the control group and basal feed treatment supplemented with Moringa leaves meal with the concentration of 2,5; 5; 7,5; and 10\%. Feeding and drinking prepared ad libitum. The data were analyzed by normal distribution patterns and data homogeineity, then to find out the differences between each groups, the data were analyzed by one way-ANOVA. The results showed that the addition of Moringa leaves meal in duck feed did not have a significant effect $(\mathrm{P}>0.05)$ in the weight of the heart, spleen, stomach, and abdominal fat of Pengging duck. This study concluded that Moringa leaves meal as feed additive did not increase the weight of the heart, spleen, and stomach, and did not decrease the abdominal fat of Pengging ducks.
\end{abstract}

Keywords: Moringa leaves meal, heart, spleen, stomach, abdominal fat, Pengging duck. 


\section{PENDAHULUAN}

Industri peternakan yang ada di Indonesia menghasilkan sekitar 3.467 .600 ton daging. Pemasok daging terbesar, yaitu ayam sebesar $70,9 \%$, daging sapi $14,9 \%$, dan itik hanya mampu menghasilkan 36.390 ton atau hanya sebesar 1,04\% dari total produksi daging Indonesia (Ditjen PKH, 2018). Berdasarkan data tersebut menunjukkan bahwa produksi daging itik yang ada di Indonesia masih sangat rendah, walaupun sumbangan ternak itik masih relatif rendah, tetapi memiliki potensi untuk dikembangkan dan hal ini ditunjukkan oleh peluang pasar yang cukup besar (Daud dkk., 2016). Selain mengkonsumsi daging unggas, sebagian masyarakat juga mengkonsumsi organ bagian dalam, yaitu jantung, ampela, usus, limpa, dan hati (Wandono dkk., 2013). Hasil ikutan seperti organ bagian dalam masih banyak dicari oleh masyarakat karena memiliki nilai jual yang relatif murah, namun memiliki nilai gizi yang cukup baik (Suparyanto, 2006). Berdasarkan konsumsi masyarakat yang cukup tinggi tersebut, maka diperlukan adanya upaya dalam meningkatkan produksi organ dalam itik, yaitu melalui pendekatan pada aspek pakan karena pakan merupakan faktor dari manejemen pemeliharaan yang dapat mempengaruhi pertumbuhan dan produksi ternak. Pakan yang berkualitas baik dapat diperoleh dengan menambahkan feed additive atau imbuhan pada pakan (Lestari dkk., 2017). Salah satu bahan alami yang dapat dimanfaatkan sebagai imbuhan pada pakan adalah daun kelor (Moringa oleifera. Lam).

Daun kelor banyak dimanfaatkan secara luas oleh masyarakat karena kandungan nutrisinya yang relatif lengkap. Ketersediaan daun kelor yang cukup melimpah serta tersedia sepanjang tahun menjadi salah satu pertimbangan untuk dimanfaatkan sebagai imbuhan pakan yang relatif murah (Wahyu, 2016). Daun kelor mengandung berbagai macam asam amino, antara lain asam amino aspartat, glutamat, alanin, valin, leusin, isoleusin, histidin, lisin, arginin, venilalanin, triftopan, sistein, dan metionin (Simbolan et al., 2007). Ekstrak daun kelor memiliki aktivitas antioksidan yang dikenal sebagai penangkal radikal bebas dan memberikan perlindungan yang signifikan terhadap kerusakan oksidatif, sehingga daun kelor dapat digunakan sebagai imbuhan pakan ternak (Agoyi et al., 2015). Daun kelor selain menjadi sumber vitamin dan asam amino yang baik, juga digunakan dibidang medis sebagai obat (Banjo, 2012). Penelitian yang dilakukan oleh Khan et al. (2017) menunjukkan bahwa suplementasi daun kelor pada pakan ayam pedaging sebesar 1,2\% dapat meningkatkan kesehatan usus melalui peningkatan mikroarsitektur usus dan jumlah sel dalam usus, serta mampu meningkatkan berat badan dan panjang usus halus ayam pedaging. Penggunaan daun kelor sebagai pakan tambahan pada ayam pedaging dapat menjadi antioksidan kuat yang dapat melindungi dan menjaga kondisi ayam terhadap stress oksidatif, sehingga memberikan hasil berupa tingkat pertumbuhan dan kualitas karkas yang lebih baik (Cwayita, 2014). Penelitian yang dilakukan oleh Ariyansah (2018) menunjukkan bahwa imbuhan tepung daun kelor pada ayam broiler mampu menurunkan kandungan lemak abdominal secara signifikan. Penurunan lemak abdominal disebabkan oleh meningkatnya kandungan serat kasar dalam pakan.

Kandungan tanaman kelor yang paling menonjol adalah antioksidan, terutama pada daunnya yang mengandung antioksidan tinggi. Berdasarkan uji fitokimia, daun kelor mengandung tanin, steroid, triterpenoid, flavonoid, saponin, antarquinon, dan alkaloid, yang semuanya merupakan antioksidan (Kasolo et al., 2010). Penelitian yang dilakukan oleh Sjofjan (2008) menunjukkan bahwa penambahan daun kelor dalam pakan dapat menghasilkan peningkatan konsumsi pakan, pertambahan bobot hidup, konversi pakan, berat karkas, faktor efisiensi produksi, dan Income Over Feed Cost (IOFC). Berbeda dengan hasil penelitian sebelumnya, Rehman et al. (2018) menemukan bahwa suplementasi serbuk daun Moringa oleifera pada tingkat konsentrasi $12 \mathrm{~g} / \mathrm{kg}$ dalam makanan ayam pedaging meningkatkan indikator kualitas daging serta indeks bobot, persentase abu dan indeks kepadatan tulang tibia (Rehman et al. 2018). Berbagai peran penting daun kelor sebagai imbuhan pakan ternak sampai dengan saat ini masih terus dikembangkan sehingga penelitian ini 
sangat penting dilakukan. Tujuan dari penelitian ini adalah menganalisis pengaruh imbuhan tepung daun kelor pada pakan terhadap bobot beberapa jantung, limpa dan lambung, serta lemak abdominal itik pengging.

\section{METODE PENELITIAN}

Penelitian dilakukan di peternakan rakyat di Dukuh Kalijaran, Desa Bawak, Cawas Klaten dan di Laboratorium Biologi Struktur dan Fungsi Hewan, Fakultas Sains dan Matematika, Universitas Diponegoro. Bahan yang digunakan adalah 60 ekor itik pengging betina.

\section{Persiapan Kandang dan Pemeliharaan Hewan Percobaan}

Kandang penelitian dibuat dengan ukuran $100 \times 150 \times 70 \mathrm{~cm}^{3}$ yang sudah dilengkapi tempat pakan dan persediaan air minum sistem infuse, antarkandang diberikan sekat menggunakan bilah bambu. Kandang penelitian berupa sistem litter dengan alas sekam padi. Hewan percobaan yang digunakan pada penelitian ini adalah itik pengging betina berjumlah 60 ekor, berumur 24 minggu dengan bobot hidup berkisar 1500-1600 gram. Itikitik tersebut ditempatkan ke dalam 20 buah petak kandang untuk diaklimasi selama satu minggu. Masing-masing petak kandang berisi empat ekor itik, setiap ekor itik diberi tanda pada pergelangan kaki menggunakan kabel ties berwarna putih. Itik dipelihara pada temperatur kandang $28-34^{\circ} \mathrm{C}$.

\section{Pembuatan Pakan}

Pakan dibuat setiap satu minggu sekali sesuai dengan konsentrasi tepung daun kelor yang digunakan pada penelitian ini, dengan cara mencampur beberapa bahan pakan, yaitu dedak padi, konsentrat, dan tepung daun kelor. Pencampuran bahan pakan dimulai dari penambahan tepung daun kelor pada konsentrat, kemudian campuran diaduk hingga terbentuk campuran bahan pakan yang homogen. Selanjutnya, campuran tepung daun kelor dan konsentrat yang telah homogen ditambahkan ke dalam dedak padi, diaduk hingga rata sampai dihasilkan campuran pakan yang juga homogen. Pakan perlakuan diberikan selama 6 minggu, dimulai pada itik umur 26 hingga 32 minggu. Pakan yang diberikan sesuai dengan komposisi pakan per perlakuan. Tepung daun kelor diperoleh dari Flozindo Purbalingga, Jawa Tengah. Komposisi bahan pakan dan kandungan nutrisi pakan sesuai dengan penelitian Kasiyati et al. (2019) yang disajikan pada Tabel 1. Pakan itik yang digunakan selama penelitian berbentuk mash semibasah yang sudah diformulasikan dengan tepung daun kelor. Pakan itik telah disesuaikan dengan kebutuhan nutrisi itik petelur periode produksi atau periode dewasa kelamin (>24 minggu).

Tabel 1. Komposisi bahan pakan dan kandungan nutrisi pakan itik petelur periode produksi

\begin{tabular}{lccccc}
\hline \multicolumn{1}{c}{ Bahan pakan (\%) } & \multicolumn{5}{c}{ Konsetrasi Tepung Daun Kelor (\%) } \\
\cline { 2 - 6 } & $\mathbf{0}$ & $\mathbf{2 , 5}$ & $\mathbf{5}$ & $\mathbf{7 , 5}$ & $\mathbf{1 0}$ \\
\hline Dedak padi & 60 & 60 & 60 & 60 & 60 \\
Konsentrat $^{*}$ & 40 & 37,5 & 35 & 32,5 & 30 \\
Tepung daun kelor & 0 & 2,5 & 5 & 7,5 & 10 \\
Total & 100 & 100 & 100 & 100 & 100 \\
Kandungan nutrisi hasil analisis laboratorium & & & \\
Energi metabolis (kkal/kg) & 2630,50 & 2680,90 & 2790,57 & 2840,80 & 2880,45 \\
Protein kasar (\%) & 17,22 & 17,56 & 18,30 & 19,56 & 20,08 \\
Lemak (\%) & 6,16 & 5,40 & 5,25 & 4,25 & 4,16 \\
Kalsium (\%) & 1,82 & 2,05 & 2,56 & 2,90 & 3,04 \\
Serat kasar (\%) & 3,07 & 3,25 & 3,57 & 4,09 & 4,21 \\
\hline
\end{tabular}

*Konsentrat untuk bebek petelur diproduksi oleh pabrik pakan ternak, mengandung protein kasar 37\%, lemak kasar 3,5\%, serat kasar 6\%, kalsium 13-14\%, fosfor 14,18\%, dan abu 40\% (Kasiyati et al., 2019). 


\section{Pengukuran Variabel Penelitian}

Variabel yang digunakan pada penelitian ini adalah bobot organ dalam (jantung, limpa, dan lambung) dan lemak abdominal itik pengging (Anas platyrhyncos). Pengukuran bobot beberapa organ dalam (jantung, limpa, dan lambung) dan lemak abdominal menggunakan timbangan digital merk HWH Osaka Series dengan kepekaan 0,01 gram (Sulistyoningsih, 2015). Persentase bobot organ dalam diperoleh dengan membandingkan bobot jantung, limpa, dan lambung dengan bobot badan akhir, kemudian dikalikan 100\% (Swito dkk., 2015). Berat lemak abdominal itik dapat diketahui dengan cara menimbang lemak yang didapat dari lemak yang berada pada sekeliling ventrikulus dan lapisan yang menempel antara otot abdominal serta usus dan selanjutnya ditimbang. Persentase lemak abdomen (\%), diperoleh dari bobot lemak abdomen (g) dibagi bobot hidup (g/ekor) dikali 100.

\section{Rancangan Penelitian dan Analisis Data}

Rancangan percobaan yang digunakan dalam penelitian ini adalah Rancangan Acak Lengkap (RAL) dengan 5 jenis perlakuan, terdiri atas satu perlakuan berupa kelompok kontrol tanpa imbuhan tepung daun kelor (0\%), kelompok pakan basal dengan imbuhan tepung daun kelor masingmasing konsentrasi 2,5; 5; 7,5; dan 10\%. Masingmasing perlakuan terdiri atas 3 ulangan, setiap ulangan berisi 3 ekor itik betina. Data yang diperoleh dianalisis dengan pola distribusi normal dan homogenitas data. Perbedaan antarkelompok diketahui dengan melakukan ANOVA (Analysis of Variance). Jika terdapat perbedaan antarkelompok secara signifikan, dilanjutkan dengan uji Duncan dengan taraf signifikansi 5\% (Dowdy and Wearden, 1991). Analisis korelasi dan regresi juga dilakukan untuk melihat keterkaitan antarvariabel penelitian. Analisis data menggunakan aplikasi SPSS versi 16.0

\section{HASIL DAN PEMBAHASAN}

Hasil analisis terhadap variabel penelitian yang meliputi bobot beberapa organ dalam itik pengging, yaitu bobot jantung, limpa, lambung, dan bobot lemak abdominal setelah diberi perlakuan dengan menambahkan suplemen tepung daun kelor (Moringa oleifera Lam.) pada pakan dengan konsentrasi 2,5; 5; 7,5; dan 10\% dapat dilihat pada Tabel 2. Berdasarkan analisis data menunjukkan bahwa imbuhan tepung daun kelor tidak berpengaruh nyata terhadap sejumlah variabel yang diamati $(\mathrm{P}>0,05)$. Hal tersebut dapat terjadi karena imbuhan suplemen tepung daun kelor pada pakan dengan konsentrasi yang diberikan tidak menghasilkan pengaruh terhadap peningkatan bobot jantung, limpa, dan lambung, serta tidak menurunkan bobot lemak abdominal itik pengging yang diharapkan dapat meningkatkan produktivitas ternak. Fakta ini mungkin berkaitan dengan adanya zat antinutrisi yang terkandung dalam daun kelor, yaitu tanin dan saponin.

Zat antinutrisi merupakan substansi yang dapat mempengaruhi aspek-aspek biologi, seperti terganggunya fungsi metabolisme tubuh dan turunnya produktivitas ternak. Zat ini terdapat dalam berbagai bentuk bahan pakan yang berasal dari tanaman yang dapat dikonsumsi oleh hewan ternak, umumnya dipengaruhi secara genetik, sehingga tanaman dapat memproduksi antinutrisi dalam organ tubuhnya. Zat-zat antinutrisi, yaitu alkaloida, asam amino toksik, tanin, saponin, dan lain-lain (Zamsari dkk., 2012). Tanin merupakan senyawa antinutrisi yang dapat menurunkan palatabilitas dan kecernaan (Siregar, 1994). Tanin, selain mengikat protein dan asam-asam amino, juga berikatan dengan senyawa makromolekuler lain seperti karbohidrat, terutama amilum dan selulosa, mineral $\mathrm{Ca}, \mathrm{P}, \mathrm{Fe}$, dan $\mathrm{Mg}$, serta vitamin $\mathrm{B} 12$. Apabila tanin berada di dalam saluran pencernaan dapat menutupi lumen saluran pencernaan yang menyebabkan penyerapan zat-zat nutrisi pakan menjadi berkurang (Haril dkk., 2017). Selain tanin, zat antinutrisi yang lain adalah saponin. Saponin menurunkan permeabilitas sel mukosa usus halus yang dapat mengakibatkan penghambatan metabolisme nutrisi dan menyebabkan absorpsi zat-zat gizi dalam saluran pencernaan menjadi terganggu. Unggas lebih sensitif terhadap saponin daripada ternak monogastrik lainnya. Saponin memberikan pengaruh terhadap proses metabolisme nutrisi dengan cara menghambat kerja enzim sehingga dapat menghambat produktivitas 
dan pertumbuhan ternak (Sutedja dkk., 1997).

Zat antinutrisi dalam daun kelor dapat membuat pakan tidak palatabel karena rasa pahit yang dihasilkan oleh tanin yang terkandung di dalam daun kelor dapat menggangu proses absorpsi zat-zat nutrisi dalam saluran pencernaan. Akibatnya, terjadi defisiensi zat nutrisi yang dapat berimbas pada bobot potong ternak yang rendah dan mempengaruhi besaran persentase karkas dan nonkarkas (giblet) (Haril dkk., 2017). Jantung dan limpa merupakan bagian dari organ dalam yang sistem kerjanya dipengaruhi oleh zat antinutrisi yang masuk dalam tubuh unggas melalui pakan. Organ dalam pada setiap mahluk hidup terutama hewan ternak sangat menentukan performa dari ternak itu sendiri (Pangesti dkk., 2016).

Tabel 2. Hasil analisis bobot beberapa organ dalam dan lemak abdominal itik pengging (Anas platyrhyncos) setelah suplementasi tepung daun kelor

\begin{tabular}{lccccc}
\hline \multirow{2}{*}{ Parameter } & \multicolumn{5}{c}{ Konsentrasi tepung daun kelor (\%) } \\
\cline { 2 - 6 } & $\mathbf{0}$ & $\mathbf{2 , 5}$ & $\mathbf{5}$ & $\mathbf{7 , 5}$ & $\mathbf{1 0}$ \\
\hline $\begin{array}{l}\text { Bobot } \\
\text { jantung }\end{array}$ & $0,68 \pm 0,16$ & $0,85 \pm 0,39$ & $0,64 \pm 0,05$ & $0,66 \pm 0,005$ & $0,66 \pm 0,12$ \\
$\begin{array}{l}\%) \\
\text { Bobot }\end{array}$ & $0,08 \pm 0,02$ & $0,08 \pm 0,02$ & $0,07 \pm 0,03$ & $0,07 \pm 0,005$ & $0,06 \pm 0,03$ \\
limpa $(\%)$ & & & & \\
$\begin{array}{l}\text { Bobot } \\
\text { lambung }\end{array}$ & $2,79 \pm 0,06$ & $2,68 \pm 0,10$ & $3,00 \pm 0,144$ & $3,07 \pm 0,325$ & $3,22 \pm 0,287$ \\
$\begin{array}{l}(\%) \\
\text { Bobot }\end{array}$ & $2,19 \pm 0,64$ & $1,25 \pm 0,80$ & $1,97 \pm 1,10$ & $2,09 \pm 0,69$ & $1,51 \pm 0,266$ \\
lemak \\
$\begin{array}{l}\text { abdominal } \\
(\%)\end{array}$
\end{tabular}

Keterangan : Data yang ditampilkan berupa rata-rata \pm SD

Berdasarkan hasil analisis persentase bobot jantung (Tabel 2) antara perlakuan dengan kontrol tidak memberikan pengaruh yang signifikan $(\mathrm{P}>0,05)$. Pengaruh yang tidak signifikan tersebut diduga karena rendahnya senyawa bioaktif yang terdapat di dalam tepung daun kelor. Tanin dan saponin dalam konsentrasi yang rendah sebagian akan dikeluarkan dari saluran pencernaan bersama feses dan sebagian kecil yang berhasil diabsorpsi oleh sel-sel epitel pada duodenum usus halus. Konsentrasi yang rendah dari kedua senyawa bioaktif yang diabsorpsi akan mengalami detoksifikasi oleh sel-sel hepar sebelum diedarkan ke seluruh tubuh melalui pembuluh darah. Berdasarkan hal tersebut kedua senyawa bioaktif ini tidak menimbulkan efek toksik dan perubahan ukuran pada organ jantung, atau organ jantung tetap berada pada kondisi skala isometrik. Hal tersebut didukung oleh pendapat Sunarno et al. (2019) yang menyatakan bahwa tannin dan saponin pada konsentrasi rendah tidak bersifak toksik terhadap organ viscera termasuk jantung. Maya
(2002) menyatakan bahwa organ jantung tidak rentan terhadap senyawa antinutrisi yang bersifat sitotoksik pada konsentrasi yang rendah. Keberadaan senyawa ini akan mengalami detoksifikasi di dalam organ hepar sehingga pengaruh sitotoksik dari senyawa tersebut akan hilang atau mengalami penurunan. Senyawa sitotoksik dalam tepung daun kelor yang telah mengalami detoksifikasi tidak mempengaruhi kerja jantung dalam mengedarkan darah ke seluruh tubuh (Pangesti dkk., 2016).

Hasil analisis persentase bobot limpa menunjukkan bahwa pemberian suplemen tepung daun kelor menghasilkan perbedaan yang tidak nyata $(\mathrm{P}>0,05)$. Hal tersebut diduga karena senyawa bioaktif yang terkandung di dalam daun kelor tidak menimbulkan efek toksik pada limpa sehingga tidak mempengaruhi aktivitas limpa yang berperan dalam sistem pertahanan tubuh. Hal ini mengakibatkan ukuran limpa pada kelompok itik yang diberi imbuhan tepung daun kelor tidak berbeda secara signifikan jika dibandingkan 
dengan kelompok kontrol. Sjofjan (2008) menyatakan bahwa penggunaan suplemen tepung daun kelor dalam pakan tidak memberikan pengaruh yang membahayakan pada kinerja limpa sehingga tidak menyebabkan pertambahan ukuran dan pembengkakan limpa.

Persentase bobot lambung pada penelitian ini juga tidak berbeda nyata $(\mathrm{P}>0,05)$ antara kontrol dengan kelompok yang disuplementasi tepung daun kelor $2,5-10 \%$. Perbedaan yang tidak nyata antara kelompok perlakuan dengan kontrol diduga karena senyawa bioaktif, seperti tannin dan saponin dalam tepung daun kelor tidak mempengaruhi aktivitas mekanis atau kimiawi sel-sel epitel lambung. Hal ini berarti, berbagai jenis sel epitel pada lambung, seperti sel parietal (penghasil $\mathrm{HCl}$ ), sel mukus leher (penghasil mukus), sel Chief (penghasil pepsinogen), dan sel $\mathrm{G}$ (penghasil hormon gastrin) tidak mengalami perubahan dan bekerja pada kondisi yang normal (Alfian dkk., 2018). Akoso (1998) berpendapat bahwa ukuran ventrikulus dipengaruhi oleh aktivitasnya. Aktivitas otot ventrikulus akan terjadi apabila makanan masuk ke dalam ventrikulus. Menurut pernyataan Yuwanta (2004) ukuran dan kekuatan ventrikulus dipengaruhi oleh kebiasaan makan unggas tersebut dan banyaknya pakan yang dikonsumsi. Pakan unggas dengan kandungan senyawa bioaktif, seperti tannin dan saponin pada konsentrasi yang rendah tidak memberi pengaruh terhadap perubahan ukuran ventrikulus. Tepung daun kelor dengan kandungan serat kasar 6\% seperti pada penelitian ini tidak terbukti meningkatkan ukuran ventrikulus itik pengging, hal ini berarti keberadaan serat kasar selama di dalam lambung tidak mempengaruhi aktivitas mekanis, kimiawi, atau seluler.

Lemak abdominal merupakan lemak yang terdapat pada sekeliling ventrikulus dan lapisan yang menempel antara otot abdominal serta usus (Setiawan dan Sujana, 2009). Hasil analisis persentase bobot lemak abdominal pada penelitian ini menunjukkan bahwa pemberian suplemen tepung daun kelor tidak memberikan pengaruh yang nyata $(\mathrm{P}>0,05)$ pada semua kelompok itik yang disuplementasi tepung daun kelor. Berkaitan dengan bobot lemak abdominal yang tidak berbeda nyata $(\mathrm{P}>0,05)$ antara kelompok kontrol dengan kelompok yang disuplementasi oleh tepung daun kelor diduga karena konsumsi energi dalam tubuh itik tidak melebihi kebutuhan energi hidup pokok karena dengan adanya energi yang berlebih tersebut, kemudian akan disimpan dalam bentuk lemak, salah satunya adalah lemak yang terdapat pada rongga perut. Tama dkk. (2017) berpendapat bahwa pembentukan lemak tubuh pada unggas terjadi karena adanya kelebihan energi yang dikonsumsi dari makanan. Energi yang digunakan tubuh umumnya berasal dari karbohidrat dan cadangan lemak. Sumber karbohidrat dalam tubuh mampu memproduksi lemak tubuh yang disimpan di sekeliling organ dalam dan di bawah kulit. Menurut pendapat Dalton and Loth (1985) bobot lemak abdominal akan meningkat dengan bertambahnya energi metabolis pakan. Soeparno (2005) menyatakan bahwa lemak karkas yang tinggi sebagai akibat dari perlakuan pakan berenergi tinggi yang menyebabkan sintesis lemak dan karbohidrat lebih besar dibandingkan dengan perlakuan pakan berenergi rendah sehingga terjadi kenaikan persentase lemak intramuskular dan menurunkan kadar air. Sumber karbohidrat dalam tubuh mampu memproduksi lemak tubuh yang kemudian disimpan pada berbagai bagian tubuh, yaitu di sekeliling organ dalam dan di bawah kulit (Setiawan dan Sujana, 2009).

Pembentukan lemak abdominal pada itik, diduga ada kaitannya dengan kandungan serat kasar dalam pakan yang dikonsumsi sehingga mengakibatkan bobot lemak abdominal yang dihasilkan juga berbeda, bertambahnya kandungan serat kasar maka menyebabkan kandungan lemak abdominal akan menurun, karena dengan tingginya kandungan serat kasar maka daya cerna makanan akan lebih rendah sehingga membutuhkan waktu yang lama untuk mencerna makanan. Haril dkk. (2017) menyatakan bahwa serat kasar yang berasal dari pakan setelah dikonsumsi akan mengikat asam empedu sehingga menyebabkan fungsi empedu untuk membantu penyerapan lemak akan terhambat. Selanjutnya, asam empedu yang sudah terikat oleh serat kasar akan dikeluarkan dalam bentuk feses sehingga mengakibatkan penurunan deposisi lemak abdominal. Proses pencernaan serat kasar yang tinggi pada pakan membutuhkan energi yang lebih banyak sehingga ayam tidak memiliki 
energi yang disimpan dalam bentuk lemak.

Hasil analisis korelasi dan regresi antarvariabel penelitian disajikan pada Tabel 3 . Hasil analisis korelasi menunjukkan nilai positif, yaitu antara bobot lemak abdominal dengan bobot limpa $(r=0,67)$. Artinya, bahwa peningkatan bobot lemak abdominal mempunyai keterkaitan yang erat dengan peningkatan bobot limpa. Informasi ini diperkuat dengan analisis regresi yang menghasilkan pola hubungan linier antara bobot lemak abdominal dengan bobot limpa dengan koefisien determinasi sebesar 49,9\%. Hasil tersebut menunjukkan peningkatan bobot lemak abdominal berpengaruh nyata $(\mathrm{P}=0,003)$ pada peningkatan bobot limpa. Berdasarkan persamaan linier pada Tabel 3 dapat diperjelas bahwa perubahan satu satuan bobot lemak abdominal akan meningkatkan bobot limpa sebesar 0,023 satuan. Hasil korelasi dan regresi untuk bobot lemak abdominal dengan bobot jantung dan bobot lemak abdominal dengan bobot lambung menunjukkan tidak berbeda nyata (Tabel 3). Fakta ini memperlihatkan bahwa perubahan bobot lemak abdominal tidak mempunyai keterkaitan yang erat dengan bobot jantung maupun bobot lambung.

Tabel 3. Hasil analisis korelasi dan regresi linear antarvariabel penelitian

\begin{tabular}{lcccc}
\hline $\begin{array}{c}\text { Keterkaitan antar } \\
\text { variabel }\end{array}$ & Nilai $\mathbf{r}$ & $\mathbf{R}^{2}$ & Sig.(P<0,05) & Persamaan \\
\hline $\begin{array}{l}\text { Bobot lemak } \\
\text { abdominal dengan } \\
\text { bobot limpa }\end{array}$ & 0,676 & $49,9 \%$ & 0,003 & $\mathrm{y}=0,034+0,023 \mathrm{x}$ \\
$\begin{array}{l}\text { Bobot lemak } \\
\text { abdominal dengan } \\
\text { bobot jantung }\end{array}$ & $-0,291$ & $9,4 \%$ & 0,267 & $\mathrm{y}=0,841-0,77 \mathrm{x}$ \\
$\begin{array}{l}\text { Bobot lemak } \\
\text { abdominal dengan } \\
\text { bobot lambung }\end{array}$ & 0,106 & $2 \%$ & 0,509 & $\mathrm{y}=2,863+0,051 \mathrm{x}$ \\
\hline Keterangan r: koefisien korelasi, $\mathrm{R}^{2}$ koefisien determinasi & &
\end{tabular}

Keterangan $\mathrm{r}$ : koefisien korelasi, $\mathrm{R}^{2}$ koefisien determinasi

Fouad and El-Senousey (2014) menyatakan bahwa faktor nutrisi mempengaruhi deposisi lemak abdomen pada tubuh ayam. Menurut pernyataan Pratikno (2011) deposisi lemak dalam tubuh ayam pedaging terjadi melalui proses lipogenesis. Lipogenesis adalah proses deposisi lemak yang meliputi proses sintesis asam lemak dan kemudian sintesis trigliserida yang terjadi di hati pada daerah sitoplasma dan mitokondria, serta jaringan adiposa (Soegondo, 2006). Glukosa atau protein yang tidak segera digunakan oleh tubuh sebagian besar tersimpan sebagai trigliserida (Soegondo, 2006). Sebagian besar atom karbon yang berasal dari glukosa dan asam amino yang berlebihan akan disintesis menjadi trigliserida. Trigliserida akan membentuk kilomikron dan masuk ke dalam limpa, kemudian ke dalam aliran darah (Fouad and Senousey, 2014). Oleh karena itu, bertambahnya konsumsi pakan unggas maka dapat menstimulasi pembentukan lemak abdominal. Deposisi lemak, selanjutnya akan menghasilkan trigliserida yang masuk ke dalam limpa untuk selanjutnya dialirkan ke seluruh tubuh melalui darah sehingga meningkatnya trigliserida yang dibentuk akan menyebabkan ukuran limpa bertambah karena adanya peningkatan aktivitas dan fungsi pada limpa. Etriwati dkk. (2017) menyatakan bahwa limpa merupakan organ pertahanan sekunder yang berfungsi untuk memproduksi sel-sel limfosit dan berperan penting dalam menahan agen yang berhasil mencapai sirkulasi darah guna menahan invasi organisme atau toksin sebelum menyebar lebih luas. Apabila fungsi limpa bertambah maka terjadi perubahan pada konsistensi dan ukuran limpa. Limpa berfungsi menyaring material asing, berupa mikroorganisme serta membuang eritrosit yang tua. Proses ini berlangsung pada bagian pulpa merah (Fry and McGavin, 2012).

\section{KESIMPULAN}

Berdasarkan penelitian yang telah dilakukan 
dapat disimpulkan bahwa penambahan tepung daun kelor (Moringa oleifera Lam.) dengan konsentrasi $2,5 \% ; 5 \% ; 7,5 \%$ dan $10 \%$ pada pakan tidak mengubah bobot jantung, limpa, dan lambung dan tidak menurunkan bobot lemak abdominal itik pengging (Anas plathyryncos).

\section{DAFTAR PUSTAKA}

Agoyi, E. E., E. A. Padonou., W. Amoussa., E. Achille., Assogbadjo, R. G. Kakaï., and B. Sinsin. 2015. Morphological Variation, Cultivation Techniques and Management Practices of Moringa oleifera in Southern Benin (West Africa). International Journal of Agronomy and Agricultural Research (IJAAR). 6(3): 97105.

Akoso, T. 1998. Kesehatan Unggas Panduan Bagi Petugas Teknis, Penyuluhan, dan Peternak. Kanisius. Yogyakarta

Alfian, M. A. J., Sunarno., M. F. Zulfikar., dan A. Rifa'i. 2018. Kandungan Antioksidan dan Kolesterol Dalam Daging Broiler (Galus gallus Domestica) Hasil Pemberian Suplemen dalam Pakan Dari Tepung Daun Pegagan dan Bayam Merah. Buletin Anatomi dan Fisiologi. 3(1): 126-132.

Ariyansah, M. 2018. Pengaruh Pemberian Tepung Daun kelor (Moringa oleifera) terhadap Persentase Lemak Abdominal dan Kadar Lemak Daging Ayam Broiler. Publikasi Ilmiah. Fakultas Peternakan Universitas Mataram.

Banjo, O. S. 2012. Growth and Performance as Affected by Inclusion of Moringa oleifera Leaf Meal in Broiler Chicks Diet. J. Biol. Agric. Healthcare. 2: 35-38.

Cwayita, W. 2014. Effects of Feeding Moringa Oleifera Leaf Meal as An Additive on Growth Performance of Chicken, Physico- Chemical Shelf-Life Indicators, Fatty Acids Profiles and Lipid Oxidation of Broiler Meat. Thesis. Faculty of Science and Agriculture. University of Fort Hare, Alice, South Africa.

Dalton, J.W., dan B.D. Lott. 1985. Age and Dietary Energy Effect on Broiler Abdominal Fat
Deposition. Poultry Sci. 64: 2161-2164.

Daud, M., Mulyadi., dan F. Zahrul. 2016. Persentase Karkas Itik Peking yang Diberi Pakan dalam Bentuk Wafer Ransum Komplit Mengandung Limbah Kopi. Agripet. 16(1).

Direktorat Jendral Peternakan dan Kesehatan Hewan. 2018. Statistik Peternakan dan Kesehatan Hewan. Kementerian Pertanian RI, Jakarta.

Dowdy, S. and S. Wearden. 1991. Statistics for Research. Second Edition. A WileyInterscience Publication, New York.

Etriwati., D. Ratih., E. Handharyani., dan S. Setiyaningsih. 2017. Studi Histopatologi Limpa dan Bursa Fabricious Ayam Berpenyakit Tetelo (Newcastle Disease) pada Kasus Lapang. Jurnal Veteriner. 18(4): 510-515.

Fouad A.M., and H. K. E. Senousey. 2014. Nutritional Factors Affecting Abdominal Fat Deposition in Poultry: A review. Asian-Australasian J Anim Sci. 27:10571068.

Fry, M.M., and M.D. McGavin. 2012. Bone Marrow, Blood Cells, and lymphatic System. In McGavin., MD. Zachary JF. (Ed) Pathologic Basis of Veterinary Disease. 5th ed. St Louis. Mosby Elsivier. 698-770.

Haril, J. D., Y. Tonga., dan I. N. Kaca. 2017. Efek Penambahan Tepung Daun Kelor (Moringa Oleifera) Pada Ransum Komersial Terhadap Berat Karkas, Persentase Karkas dan Persentase Non Karkas Ayam Broiler. Gema Agro. 23(1): 53-58.

Kasiyati., Sumiati., D. R. Ekastuti., and W. Manalu. 2016. Roles of Curcumin and Monochromatic Light in Optimizing Liver Function to Support Egg Yolk Biosynthesis in Magelang Duck. International Journal of Poultry Science. 15(10): 414-424.

Kasiyati., M. A. Djaelani and Sunarno. 2019. Effect of Supplementation of Moringa 
oleifera Leaf Powder on Reproductive Performance and Ovarium Morphometry of Pengging Duck. International Journal of Poultry Science. 18(7): 340-348.

Kasolo, J. N., G. S. Bimenya., L. Ojok., J. Ochieng., and J. W. Ogwal-okeng. 2010. Phytocermical and Uses of Moringa oleifera Leaves in Ugandarrural Communities. Journal of Medicinal Plants Research. 4(9): 753-757.

Khan, I., H. Zaneb., S. Masood., M. S. Yousaf., H. F. Rehman., and H. Rehman. 2017. Effect of Moringa oleifera Leaf Powder Supplementation on Growth Performance and Intestinal Morphology in Broiler Chickens. Journal of Animal Physiology and Animal Nutrition. 101: 114-121.

Lestari, D. R., T. Suryati., dan P. S. Hardjosworo. 2017. Performa Itik Lokal (Anas platyrhynchos Javanica) yang diberi Tepung Daun Beluntas atau Kenikir sebagai Sumber Pakan Aditif. Jurnal Ilmu Produksi dan Teknologi Hasil Peternakan. 05(1): 34-40.

Maya. 2002. Pengaruh Penggunaan Medium Ganoderma lucidum Dalam Ransum Ayam Pedaging terhadap Kandungan Lemak dan Kolesterol Daging serta Organ Dalam. Skripsi. Universitas Padjajaran, Bandung.

Pangesti, U. T., M. H. Natsir., dan E. Sudjarwo. 2016. Pengaruh Penggunaan Tepung Biji Nangka (Artocarpus heterophyllus) dalam Pakan terhadap Bobot Giblet Ayam Pedaging. J.Ternak Tropika. 17(2): $58-65$.

Rehman, H F., H. Zaneb., S. Masood., M. S. Yousaf., S. Ashraf., I Khan., M. Shah., M. S. Khilji., H. Rehman. 2018. Effect of Moringa Oleifera Leaf Powder Supplementation on Pectoral Muscle Quality and Morphometric Characteristics of Tibia Bone in Broiler Chickens. Brazilian Journal of Poultry Science. 20(4): 817-824.

Setiawan, I. dan E. Sujana. 2009. Berat Akhir, Persentase Karkas, dan Lemak Abdominal Ayam Broiler yang Dipanen
Pada Umur yang Berbeda. Seminar Nasional. Fakultas Peternakan Universitas Padjajaran. Bandung.

Simbolan J. M., M. Simbolan., dan N. Katharina. 2007. Cegah Malnutrisi dengan Kelor. Kanisius, Yogyakarta.

Siregar, S. B. 1994. Ransum Ternak Ruminansia. Penerbit Swadaya, Jakarta.

Sjofjan, O. 2008. Efek Penggunaan Tepung Daun Kelor (Moringa oleifera) Dalam Pakan Terhadap Penampilan Produksi Ayam Pedaging. Seminar Nasional Teknologi Peternakan dan Veteriner, Bogor.

Soegondo S. 2006. Farmakoterapi Pada Pengendalian Glikemia Diabetes Melitus Tipe 2. Dalam: Aru W, Sudoyo, Setiyohadi B, Alwi I, Simadibrata MK, Setiati S, penyunting. Buku ajar ilmu penyakit dalam. Jilid III. Pusat Penerbitan Departemen Ilmu Penyakit Dalam Fakultas Kedokteran Universitas Indonesia, Jakarta.

Soeparno. 2005. Ilmu dan Teknologi Daging. Gajah Mada University Press Yogyakarta.

Sunarno., S. Zubaedah., A. N. S. Rini., dan E. Sekarsari. 2019. Cinnamon and Gotu Supplementation to Produce High Antioxidant and Low Cholesterol of Quail Pectoral Meat. Biosaintifika. 11(1): 148-155.

Suparyanto, A. 2006. Karakteristik Ukiuran Organ Dalam Karkas Itik Genotipe Peking x Alabio dan Peking $\mathrm{x}$ Mojosari. Lokakarya Nasional Inovasi Teknologi Dalam Mendukung Usaha Ternak Unggas Berdaya Saing. Badan Pusat Penelitian dan Pengembangan Ternak. 92-96.

Sutedja, L., L.B.S. Kardono., dan H. Agustina. 1997. Sifat Anti Protozoa Daun Katuk (Sauropus androgynus Merr). Warta Tumbuhan Obat 3(3): 47-49.

Tama, C. A., D. Septinova., dan T. Kurtini. 2017. Pengaruh Pemberian Jamu Tradisional Terhadap Bobot Hidup, Bobot Karkas, 
Bobot Giblet dan Lemak Abdominal Broiler. Jurnal Penelitian Peternakan Indonesia. Vol 1 (2):16-21.

Wahyu, E., S, Osfar., dan D. H. Irfan. 2016. Respon Pemberian Tepung Daun Kelor (Moringa oleifera) pada Pakan Ayam Petelur Terhadap Penampilan Produksi Dan Kualitas Telur. Buletin Peternakan. 40(3): 197-202.

Wandono, T. Y., B. Being., dan P. Hardi. 2013. Persentase Organ Dalam dan Deposisi Lemak Broiler yang Diberi Pakan Tambahan Tepung Kelopak Bunga Rosella (Hibiscus Sabdariffa Linn). Jurnal Sain Peternakan Indonesia. 8(1).

Yuwanta, T. 2004. Dasar Ternak Unggas. Kanisius, Yogyakarta.

Zamsari, M., Sunarso., dan Sutrisno. 2012. Pemanfaatan Tanin Alami dalam Memproteksi Protein Bungkil Kelapa Ditinjau Dari Fermentabilitas Protein Secara In Vitro. Animal Agriculture Journal. 1(1): 406. 